Volume -X, Issue-01, January-June, 2015

\title{
Customers' Attitude towards E-commerce in Bangladesh: An Empirical Study on Some Selected B2C E-commerce Sites
}

\author{
BULBUL AHAMED* \\ S.M. MONIRUL ISLAM ${ }^{* *}$ \\ KISMAT QAOM $^{* * *}$
}

\begin{abstract}
This study aims at identifying salient attributes of e-commerce sites in Bangladesh. The study tries to assess the perception of customers about the performance of major-e-commerce sites on those attributes. Eighteen potential attributes are preliminarily selected, and after conducting a pre-test on 50 sample respondents eleven salient attributes are selected for the study. Finally 108 respondents are taken as the study sample. Mertin Fishbein's multi-attribute attitude models adopted to measure the customers' attitude. Respondents were asked their belief and evaluation towards some B2C ecommerce sites. The benchmark of positive belief is hypothesized as 4 in a 5 point scale. The significance of the difference between observed mean of customers' belief and the predetermined benchmark is measured by left tailed $Z$ statistic. It is found that the sample respondents believe that the performance of the B2C e-commerce sites in Bangladesh is up to the benchmark in teams of only two attributes among the eleven. The findings of this study may be used by the existing B2C e-commerce companies as well as by the future e-commerce entrepreneurs in Bangladesh to establish a quality and customer-driven B2C e-commerce industry. Even the customers will be benefitting if the industry considers the findings of the study.
\end{abstract}

Key Words: B2C e-commerce, Attitude, Belief, Evaluation

\footnotetext{
*Assistant Professor of CSE, Department of Computer Science and Engineering, Northern University Bangladesh, E-mail: bulbul2767@gmail.com

**Assistant Professor of Marketing, Department of Business Administration, Northern University Bangladesh, E-mail: smoni_nub@yahoo.com.

****Gaduate(BBA), Northern University Bangladesh, E-mail: kqmegha@ gmail.com
} 


\section{INTRODUCTION}

Internet is now an important element for every dimensions of our life such as communication, profession, study, entertainment, shopping, business, travelling, security, governance and everything. Electronic commerce is experiencing rapid growth in Bangladesh. The most commercial use of internet is the development of e-commerce. The internet based economy is the most established virtual reality of the world today. Small retailing to heavy industrial all kinds of business are now growing in the form of e-commerce. Amazon.com, ebay.com, alibaba.com, yahoo, Google, face book are the few examples of success of multibillion Dollar global e-commerce firms. Bangladesh is an emerging developing country in south Asia with annual growth of GDP about 6\% (World Bank Country data, 2014).The size of population of Bangladesh is about 154.41 million (Bangladesh Bureau of Statistics, 2015) including 42.766 million internet users (BTRC, 2015).The growth of e-commerce is hardly dependent on the growth of internet accessibility of people. An increasing number of dealings in global trade are carried through online. Japan, China and India are the most significant e-commerce based economies in the Asian and Pacific area, with an average yearly growing rate of e-commerce turnover of 143 per cent all over the last five years (Roni Bhowmik, 2012). E-commerce is growing in Bangladesh significantly though still it is in childhood period. Hundreds of e-commerce websites are operating their business in Bangladesh.

To develop this economically potential industry in the country from the appropriate dimensions of customer's perceptions and requirements, some salient aspects have $\mathrm{t}$ be understood quite thoroughly. Because, to make the any offerings accepted to customers, they should be tailored to the needs of customers' preference.

This study is aimed:

i. To identify the main attributes of B2C e-commerce sites those are mostly important to the e-commerce customers of Bangladesh according to their evaluation to form a perception, and

ii. To measure the Bangladeshi e-commerce customers' perceptions towards the performance of major B2C e-commerce sites in Bangladesh according to the customers' belief.

Completing this research the outcome will help the e-commerce industry to improve performance as customers' desire. 


\section{LITERATURE REVIEW}

Attitude theories illustrate that consumer attitudes towards a product or service will affect consumer behavior or action against these products or services, marketers need to know the attitude of consumers towards the products it markets, and then formulate strategies to influence consumer attitudes. (Ramdhani, et al, 2012).

Online shopping or marketing is the use of technology (i.e., computer, internet) for better marketing performance. And retailers are mixing strategies to meet the demand of online shoppers; they are busy in studying consumer in the field of online shopping, to see the consumer attitudes towards online shopping and specifically studying the factors influencing consumers to shop online. Consumers' attitude in this regard is influenced by the knowledge about ecommerce sites, perceived reputation and perceived ease of use and the perceived risks regarding security of payment and refund. (Akbar Saad and James J.T. Paul, 2014)

Furthermore, in this model Fishbein (1963) says that a person's attitude toward an object is a function of his belief that the object is associated with certain attributes and evaluative responses that connected to that belief. Mathematical formulation of the model of attitude toward the object, by Fishbein can be formulated as follows:

$$
A_{0}=\sum_{i=1}^{n} b_{i} e_{i}
$$

There are different forms of e-commerce based on the type of participants in the transactions. They are Business-to-Consumer (B2C) e-commerce, Businessto-Business (B2B) e-commerce, Consumer-to-Consumer (C2C) and Peer-to-Peer (P2P) e-commerce. The use of handheld wireless devices for purchasing goods and services has been termed mobile commerce (m-commerce). (Laudon and Traver, 2014)

Eight unique features of e-commerce inspire the customers to prefer it rather than traditional business transactions, the features are Ubiquity, Global reach, Universal standards, Richness of different form of information, Interactivity, Information density, Personalization/Customization, and Social technology.(Laudon and Traver, 2014)

Jusoh and Ling (2012) investigated 'Factors Influencing Consumers' Attitude Towards E-Commerce Purchases Through Online Shopping' and the findings revealed that there is a significant relationship between e-commerce experience and attitude towards online shopping among the respondents $\left(r=-0.236^{* *}, p<\right.$ 
0.05), it is also found that there is a significant relationship between product perception and attitude towards online shopping among the respondents $(r=$ $0.471^{* *}, \mathrm{p}<0.01$ ) and there is also a significant relationship between customers' service and attitude towards online shopping among the respondents $\left(\mathrm{r}=0.459^{* *}\right.$, $\mathrm{p}<0.01)$.

Owens and Sarov (2010) conducted a research on Determinants of Consumer Attitudes towards E-commerce where they investigated the influences of various perceived risk, demographic, socioeconomic, and experience factors on consumer behavior online. The findings strongly demonstrate the importance of various socioeconomic and behavioral factors and their significant influence on consumer attitudes towards shopping online.

A research initiative was taken by Ashish Bhatt (2014) on the Indian consumers' perception on e-commerce website entitled 'Consumer Attitude towards Online Shopping in Selected Regions of Gujarat' which focused on factors which online Indian buyers keep in mind while shopping online that research found that information; perceived usefulness, perceived enjoyment and security/privacy are the five dominant factors which influence consumer perceptions on Online purchasing.

Leonard N. K. Lori (2012) conducted a research on consumer attitude on $\mathrm{C} 2 \mathrm{C}$ e-commerce to find out the influencing factors of attitude. He examined the risk and trust of buyers and sellers by developing two attitudinal models attitude towards purchasing (for buyers) and attitude towards selling (for sellers). Collecting 248 survey responses from undergraduate students, the results indicate that both trust of the seller and risk of the seller influence the buyer's attitude towards purchasing, but the model changes for seller's attitude towards selling, trust and attitude are combined into one variable and risk is not found to be an influence.

Vaishalli Nikalje (2014) tried to explore show socio-demographic (age, income and occupation), pattern of online buying (types of goods, e-commerce experience and hours use on internet) and purchase perception (product perception, customers' service and consumers' risk) affect consumers' attitude towards online shopping Pune city India and found that five factors among the nine affect consumers' attitude.

\section{METHODOLOGY OF THE STUDY}

\subsection{Variable selection}

To identify the principal attributes of e-commerce sites those have major role in forming the perception of Bangladeshi e-commerce customers to the e- 
commerce sites, we conducted a pre-test on 18 preliminary selected attributes with 50 sample customers. We determine the cut off line of $50 \%$ that means if at least $50 \%$ sample customers think the factor is important for e-commerce site then that factor was selected for final survey. In the pre-test 11 factors were above the cut-off line, so those 11 factors were selected to measure the customers perception.

TABLE-I

RESULTS OF PRETEST ON PRELIMINARY SELECTED FACTORS

\begin{tabular}{c|lc}
\hline SI. & \multicolumn{1}{|c}{ Primary factors } & $\begin{array}{c}\text { No. of } \\
\text { respondents* }\end{array}$ \\
\hline 1. & Easy information searching opportunity & $50(100 \%)$ \\
2. & Graphical interface of the website & $48(96 \%)$ \\
3. & Product comparison facility & $40(80 \%)$ \\
4. & Diversification of product collection & $47(94 \%)$ \\
5. & Accuracy of delivered product as describe in web & $49(98 \%)$ \\
6. & Less price than physical stores & $44(88 \%)$ \\
7. & Order processing time & $42(84 \%)$ \\
8. & Shipping cost & $49(98 \%)$ \\
9. & Easy and secured payment method & $48(96 \%)$ \\
10. & Return/refund facility if needed & $43(86 \%)$ \\
11. & Activeness of customer care & $35(70 \%)$ \\
12. & Reputation of the company & $22(44 \%)$ \\
13. & Web ranking of the site & $13(26 \%)$ \\
14. & Promotional offers by the site & $23(46 \%)$ \\
15. & Recommendations by others & $16(32 \%)$ \\
16. & Negative or positive feedback providing opportunity & $14(28 \%)$ \\
17. & Data loading speed of the server & $18(36 \%)$ \\
18. & Easy and short domain name & $08(16 \%)$ \\
\hline
\end{tabular}

*Note: Parentheses give percent of the total

Source: Own field survey, September 2014

\subsection{Sample Size and Data Collection}

To conduct final survey on the selected 11 attributes of e-commerce sites for measuring customers perception 108 people are selected conveniently among whom $82.4 \%$ from Dhaka city and remaining $17.6 \%$ from out of Dhaka city. 
The data are collected from the sample respondents through a structured questionnaire. To measure the perception of the respondents on selected 11 attributes of e-commerce site 5 point Likert scale are used.

\subsection{Data Analysis}

To analyze the collected data from sample respondents different models and statistical tools are used. Firstly to measure the customers' attitude towards ecommerce sites Fishbein Multi- attribute model of attitude measurement (Fishbein, M., \& Ajzen, I. 1975) is used. According to the model, 11 selected attributes of e-commerce sites are measured from two dimensions, first one is belief $\left(\mathrm{b}_{\mathrm{i}}\right)$ of customers and second one is evaluation $\left(\mathrm{e}_{\mathrm{i}}\right)$. That means customers' perception about the performance of a site on the certain attribute and the perception of importance of that attribute respectively. To identify the significance of the data regarding the belief $\left(b_{i}\right)$ of customers comparing the constructed hypothesis left tailed $\mathrm{Z}$ test is used at 5\% significance level. To analyze the demographic data of the respondent and the data on other than the selected 11 variables percentage and cumulative percentage is used. To process the data and extract the essential statistics for aforesaid methodology SPSS 16.0 is used.

\section{HYPOTHESIS CONSTRUCTION}

It is already said that the proposed model of this study has two components, belief $\left(\mathbf{b}_{\mathbf{i}}\right)$ and evaluation $\left(\mathbf{e}_{\mathbf{i}}\right)$.These components relate to perception on performance and perception on importance of an attribute. The hypothesis is proposed on the belief $\left(b_{i}\right)$.

$\mathbf{H}_{\mathbf{0}}: \mathbf{A}_{\mathbf{0}}=\mathbf{4} \leq .\left(\mathbf{b}_{\mathbf{i}}\right)$, That means customers belief (perception of performance) about each attribute of online shopping site is good(4 or above in the used five point scale)

$\mathbf{H}_{\mathrm{a}}: \mathbf{A}_{\mathbf{0}}=\mathbf{4}>$.( $\left.\mathbf{b}_{\mathrm{i}}\right)$, That means customers belief (perception of performance) about each attribute of online shopping site is not good (less than 4 in the used five point scale)

\section{Explanation of Hypothesis}

Since 5 is the maximum score of belief $\left(b_{i}\right)$ in the used scale (i.e. Likert scale), so 4 is determined as the standard positive (good) score of belief. That means if respondents believe that the performance of an online shopping website based on an attribute is 4 or above in a 5 point scale then it is has established a good (as established standard) attitude in the customers' mind. 


\section{RESULTS AND DISCUSSION}

\subsection{Demographic analysis}

The primary data are collected from 108 respondents from different divisional cities of Bangladesh. The demographic attributes of the sample respondents are as follows;

TABLE-II

\section{AGE GROUP BASIS DISTRIBUTION OF THE RESPONDENTS}

\begin{tabular}{l|c|c|c|c}
\hline \multicolumn{1}{c|}{ Age Range } & Frequency & Percent & Valid Percent & Cumulative Percent \\
\hline $15-25$ & 60 & 55.6 & 55.6 & 55.6 \\
$26-35$ & 48 & 44.4 & 44.4 & 100.0 \\
Total & 108 & 100.0 & 100.0 & \\
\hline
\end{tabular}

Young and young adult peoples are mainly interested to online shopping, for this reason the respondents are selected only from the 15 to 35 age groups. 60 respondents are from 15-25 age group and 48 respondents are from 26-35 age group.

TABLE-III

GENDER BASIS DISTRIBUTION OF THE RESPONDENTS

\begin{tabular}{lcccccc}
\hline Gender & Frequency & Percent & Valid Percent & Cumulative Percent \\
\hline Male & 73 & 67.6 & 67.6 & 67.6 \\
Female & 35 & 32.4 & 32.4 & 100.0 \\
Total & 108 & 100.0 & 100.0 & \\
\hline
\end{tabular}

Among the total 108 respondents 73 are male and 35 are female. 
TABLE-IV

DISTRIBUTION OF THE RESPONDENTS BASED ON EDUCATIONAL QUALIFICATIONS

\begin{tabular}{l|c|c|c|c}
\hline $\begin{array}{c}\text { Educational } \\
\text { Qualification }\end{array}$ & Frequency & Percent & Valid Percent & Cumulative Percent \\
\hline HSC & 6 & 5.6 & 5.6 & 5.6 \\
Hon's & 72 & 66.7 & 66.7 & 72.2 \\
Masters & 30 & 27.8 & 27.8 & 100.0 \\
Total & 108 & 100.0 & 100.0 & \\
\hline
\end{tabular}

To purchase products from e-commerce sites a minimum knowledge of computer and internet is required so education of the customers is important. $66.7 \%$ of the respondent had graduation, $27.8 \%$ respondents had master's degree and $6 \%$ respondents had higher secondary education.

TABLE-V

OCCUPATIONAL DISTRIBUTION OF THE RESPONDENTS

\begin{tabular}{l|c|c|c|c}
\hline Occupation & Frequency & Percent & Valid Percent & Cumulative Percent \\
\hline Student & 46 & 42.6 & 42.6 & 42.6 \\
Employee & 59 & 54.6 & 54.6 & 97.2 \\
others & 3 & 2.8 & 2.8 & 100.0 \\
Total & 108 & 100.0 & 100.0 & \\
\hline
\end{tabular}

Occupational status plays a great role on the customers buying behavior. Among the total respondents $97.2 \%$ were students and employees.

TABLE-VI

LOCATION-WISE DISTRIBUTION OF THE RESPONDENTS

\begin{tabular}{l|ccccc}
\hline Location & Frequency & Percent & Valid Percent & Cumulative Percent \\
\hline Dhaka & 89 & 82.4 & 82.4 & 82.4 \\
Outside Dhaka & 19 & 17.6 & 17.6 & 100.0 \\
Total & 108 & 100.0 & 100.0 & \\
\hline
\end{tabular}


Bangladesh is a small country in terms of the geographical area, and most of the developments are concentrated in/around the capital city Dhaka. The evolution of e-commerce in Bangladesh is also concentrated to the capital city. So most of the respondents (i.e. 82.4\%) are taken from Dhaka city and the remaining $17.6 \%$ from out of Dhaka city.

From the above demographic data it is observed that the online shopping is mostly preferred by the young aged group and who are educated above Higher Secondary School. They are staying in Dhaka.

In Bangladesh there are many e-commerce websites are now operating. Among those most popular and promising sites are the ones given below (according to our survey).

TABLE-VII

LIST OF MOST POPULAR AND PROMISING ONLINE SHOPPING SITES IN BANGLADESH

\begin{tabular}{lccc}
\hline E-commerce websites & Percent $\mathbf{( \% )}$ & Frequency \\
\hline ClickBD.com & 7.8 & 9 \\
AjkerDeal.com & 9.3 & 10 \\
Akhoni.com & 5.5 & 6 \\
Bikroy.com & 23.5 & 25 \\
Rokomari.com & 18.8 & 20 \\
Ekhanei.com & 12.8 & 14 \\
OLX.com & 8.7 & 9 \\
Others & 13.6 & 15 \\
Total & 100.0 & 108 \\
\hline
\end{tabular}

According to the response of the respondents of this study to the question "Which website(s) do you visit mostly for e-commerce transactions?" Based on the response of the sample respondents most of the users $(23.5 \%)$ visits bikroy.com, second most users (18.8\%) visits rokomari.com, thirdly (12.8\%) ekhanei.com.

\subsection{Media used to access the e-commerce sites}

Most of the customers of Bangladesh visit online shopping sites by clicking the link or ad in other websites; especially the ad on Face book. 
Figure 1: Ways of visiting e-commerce sites by the customers

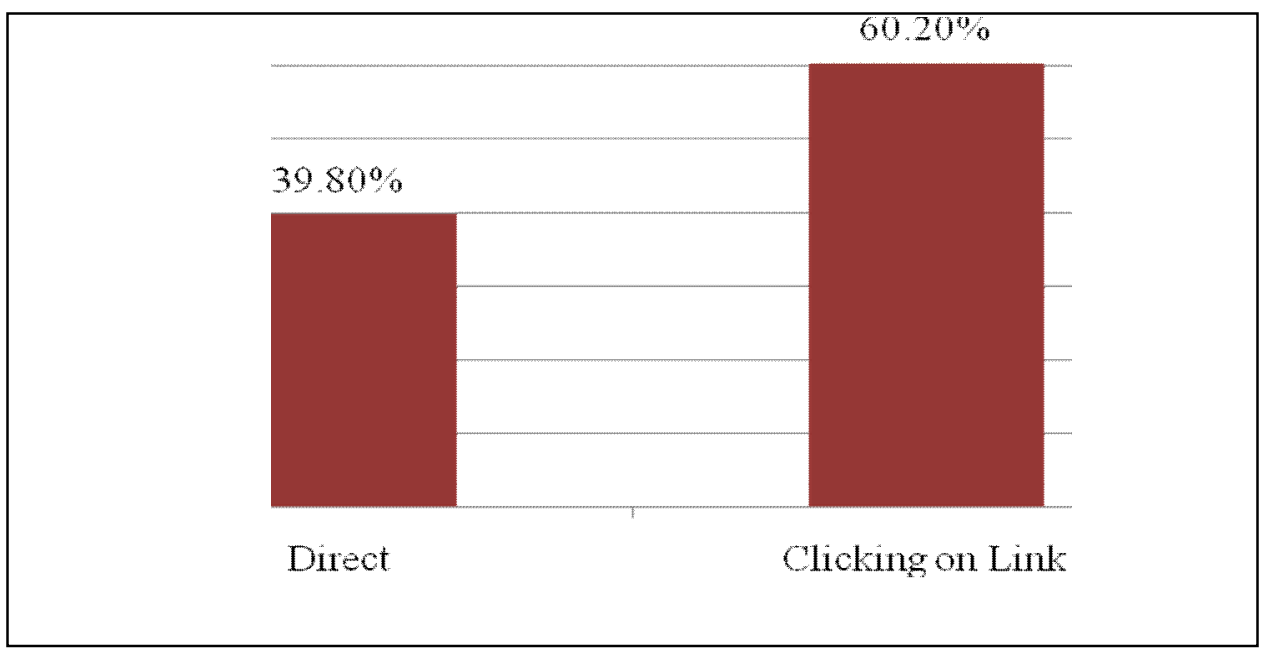

\subsection{Preferred Payment System}

One of the biggest fears of online shopping customers of our country is security on payment. And thus the system of Cash on Delivery has become mostly preferred to the customers. Other than this, payment by credit and debit card is preferred by the office going (employees) customers.

Figure 2: Preferred Payment System for B2C e-commerce transactions

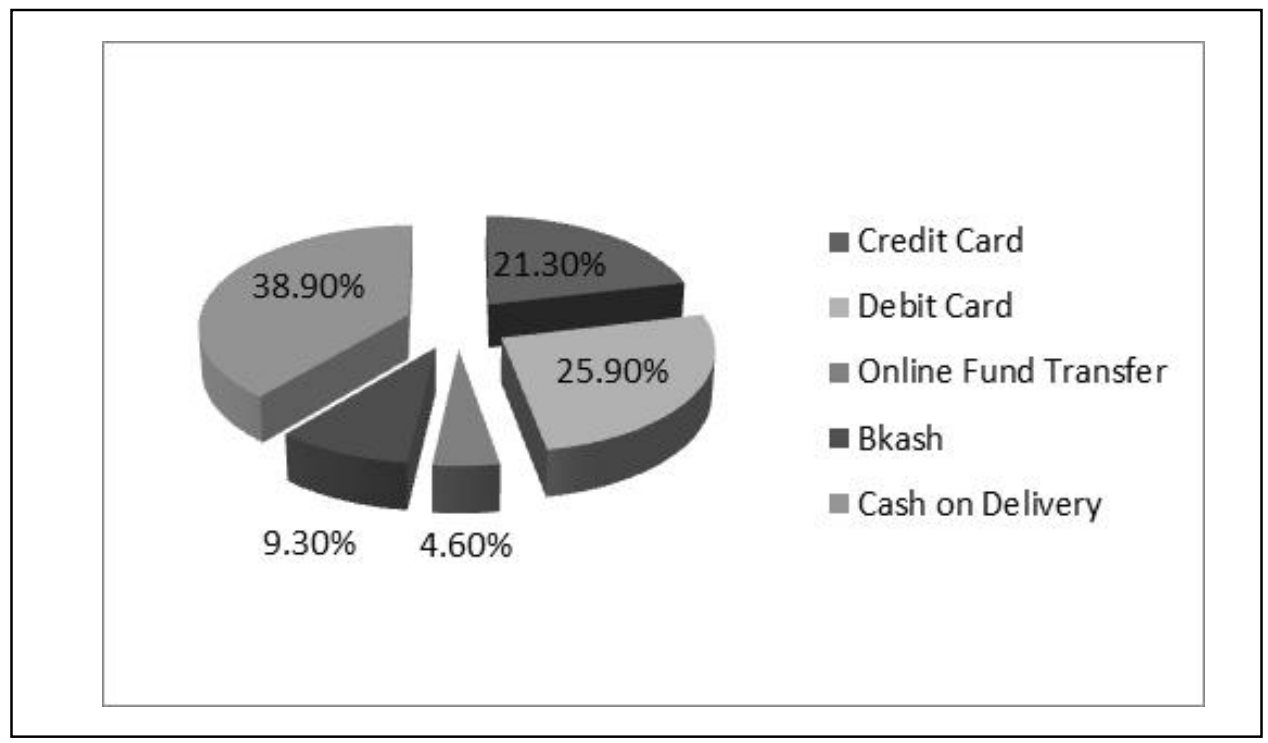




\subsection{Attitude towards online shopping}

To measure the customers' attitude towards online shopping in Bangladesh Fishbein Multi attribute model are used for attitude measurement, which was developed by Martin A. Fishbein in 1963 and published in his article entitled " $A n$ investigation of the relationships between beliefs about an object and the attitude toward that object" in the journal of Human Relations, August 1963, 16:133139. This model is constructed based on two factors, one is beliefs about the attributes of an object and another is the evaluation of feelings of the attributes of that object. The Fishbein model is symbolized as follows;

$$
A_{0}=\sum_{i=1}^{n} b_{i} e_{i}
$$

Where,

$\boldsymbol{A}_{0}=$ One's overall attitude towards the object (0)

$\boldsymbol{b}_{\boldsymbol{i}}=$ The strength of one's belief about attribute $(i)$ or factor of that object

$\boldsymbol{e}_{i}=$ The evaluation of feelings (goodness or badness) of the attribute $(i)$ or factor of that object

$$
\begin{aligned}
& \boldsymbol{n}=\text { The number of attributes considered of that object } \\
& \boldsymbol{i}=\text { individual attribute of that object }
\end{aligned}
$$

TABLE-VIII

\section{FACTOR-WISE CUSTOMERS' ATTITUDE TOWARDS E-COMMERCE SITES}

\begin{tabular}{l|l|ccc}
\hline S.L. & \multicolumn{1}{c|}{ Attributes of Online Shopping } & \multicolumn{3}{c}{$\mathrm{n}=108$} \\
\cline { 3 - 5 } & & $b_{i}$ & $e_{i}$ & $b_{i} e_{i}$ \\
\hline 19. & Easy information searching opportunity & 4.47 & 4.26 & $\mathbf{1 9 . 0 4}$ \\
20. & Graphical interface of the website & 3.94 & 3.72 & $\mathbf{1 4 . 6 6}$ \\
21. & Product comparison facility & 3.60 & 3.75 & $\mathbf{1 3 . 5 0}$ \\
22. & Diversification of product collection & 3.48 & 3.57 & $\mathbf{1 2 . 4 2}$ \\
23. & Accuracy of delivered product as described in & 3.44 & 3.49 & $\mathbf{1 2 . 0 1}$ \\
& web & & & \\
24. & Less price than physical stores & 3.83 & 3.80 & $\mathbf{1 4 . 5 5}$ \\
25. & Order processing time & 3.63 & 3.63 & $\mathbf{1 3 . 1 8}$ \\
26. & Shipping cost & 3.49 & 3.69 & $\mathbf{1 2 . 8 8}$ \\
27. & Easy and secured payment method & 3.75 & 3.76 & $\mathbf{1 4 . 1 0}$ \\
28. & Return/refund facility if needed & 3.15 & 2.90 & $\mathbf{0 9 . 1 4}$ \\
29. & Activeness of customer care & 3.01 & 3.24 & $\mathbf{0 9 . 7 5}$ \\
Total & & 39.79 & 39.81 & $\mathbf{1 4 5 . 2 3}$ \\
\hline
\end{tabular}

* Source: Field Survey, November 2014 
Figure 3: E-Commerce Sites - Factor-Wise Customers' Belief and Evaluation

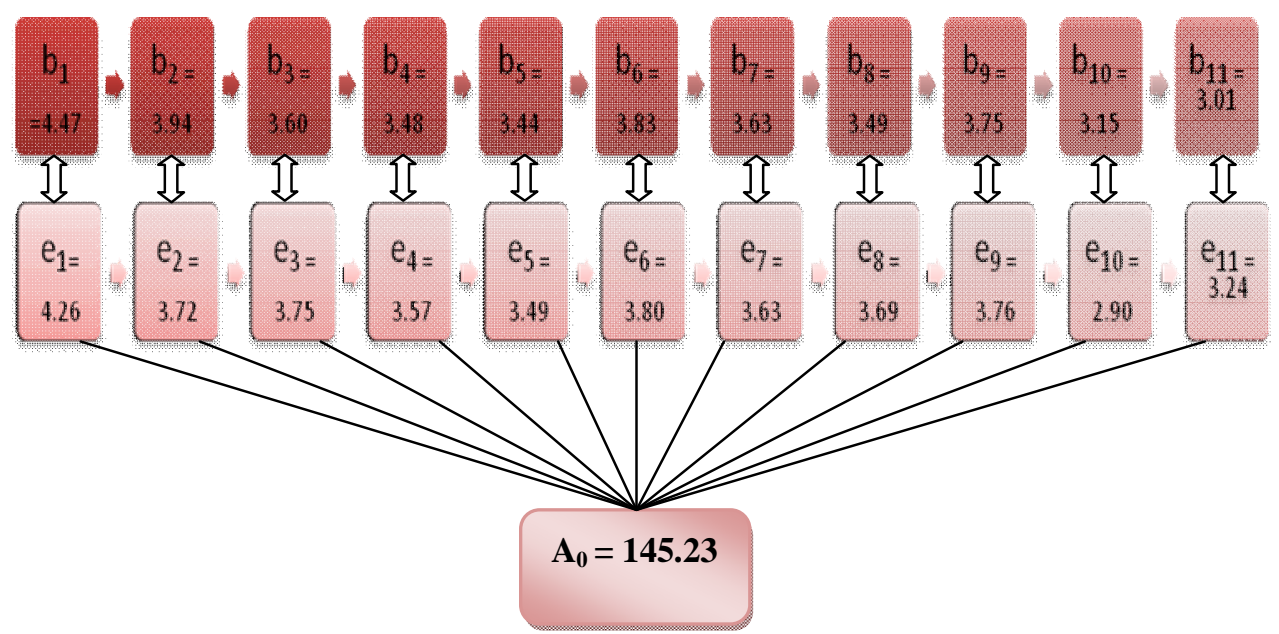

According to the model and the data presented in the above table the overall attitude of customers to the major online shopping sites in Bangladesh is;

$$
\begin{aligned}
& \begin{array}{c}
\text { Attitude Online Shopping Sites } \\
A_{0}=
\end{array} \sum_{i=1}^{n} b_{i} e_{i} \\
&=(4.47)(4.26)+(3.94)(3.72)+(3.60)(3.75)+(3.48)(3.57)+(3.44)(3.49)+(3.83)(3.80) \\
&+(3.63)(3.63)+(3.49)(3.69)+(3.75)(3.76)+(3.15)(2.90)+(3.0)(3.24) \\
&= 19.04+14.66+13.50+12.42+12.01+14.55+13.18++12.88+14.10+9.14+9.75 \\
&= \mathbf{1 4 5 . 2 3}
\end{aligned}
$$

In the above mentioned model $\boldsymbol{b}_{\boldsymbol{i}}$ indicates the strength of one's belief about attributes $(i)$ or factors of an object based on the respondent actual perception or experience from that object. And $\boldsymbol{e}_{i}$ indicates the evaluation of feelings (goodness or badness) of the attribute (i) or factor of that object based on the perceived importance of that attribute to the respondent. To measure both $b_{i}$ and $e_{i} 5$ point Likert scale is used in which 1 represents the lowest performance and lowest importance, in cases of $b_{i}$ and $e_{i}$ respectively. And 5 represent the highest performance and highest importance, in cases of $b_{i}$ and $e_{i}$ respectively; and 3 represents the middle of both. 


\subsection{Test of Hypothesis}

TABLE-IX

TEST OF HYPOTHESIS

\begin{tabular}{|c|c|c|c|c|c|c|c|c|c|c|c|}
\hline \multirow[t]{2}{*}{ S.L. } & \multirow{2}{*}{$\begin{array}{c}\text { Attributes of Online } \\
\text { Shopping }\end{array}$} & \multirow[b]{2}{*}{$\mathbf{b}_{\mathbf{i}}$} & \multicolumn{3}{|c|}{ Observed $(n=108)$} & \multicolumn{3}{|c|}{ Hypothesized } & \multicolumn{2}{|c|}{ Value of $\mathbf{Z}$ (for $\mathbf{b}_{\mathbf{i}}$ ) } & \multirow{2}{*}{$\begin{array}{c}\text { Results } \\
\qquad\left(\mathbf{H}_{0)}\right.\end{array}$} \\
\hline & & & SD & $\mathbf{e}_{\mathbf{i}}$ & $\mathbf{b}_{\mathrm{i}} \mathbf{e}_{\mathbf{i}}$ & $\mathbf{b}_{\mathrm{i}}$ & $\mathbf{e}_{\mathbf{i}}$ & $\mathbf{b}_{\mathrm{i}} \mathbf{e}_{\mathbf{i}}$ & $\begin{array}{c}\text { Comput } \\
\text { ed }\end{array}$ & $\begin{array}{c}\text { Critical (5\% } \\
\text { sig.) }\end{array}$ & \\
\hline 1. & $\begin{array}{l}\text { Easy information } \\
\text { searching } \\
\text { opportunity }\end{array}$ & 4.47 & 0.703 & 4.26 & 19.04 & 4.00 & 4.26 & 17.04 & 6.948 & -1.645 & Accepted \\
\hline 2. & $\begin{array}{l}\text { Graphical interface } \\
\text { of the website }\end{array}$ & 3.94 & 0.995 & 3.72 & 14.66 & 4.00 & 3.72 & 14.88 & -0.627 & -1.645 & Accepted \\
\hline 3. & $\begin{array}{l}\text { Product comparison } \\
\text { facility }\end{array}$ & 3.60 & 0.796 & 3.75 & 13.50 & 4.00 & 3.75 & 15.00 & -5.222 & -1.645 & Rejected \\
\hline 4. & $\begin{array}{l}\text { Diversification of } \\
\text { product collection }\end{array}$ & 3.48 & 0.704 & 3.57 & 12.42 & 4.00 & 3.57 & 14.28 & -7.676 & -1.645 & Rejected \\
\hline 5. & $\begin{array}{l}\text { Accuracy of } \\
\text { delivered product as } \\
\text { described in web }\end{array}$ & 3.44 & 0.702 & 3.49 & 12.01 & 4.00 & 3.49 & 13.96 & -8.290 & -1.645 & Rejected \\
\hline 6. & $\begin{array}{l}\text { Less price than } \\
\text { physical stores }\end{array}$ & 3.83 & 0.972 & 3.80 & 14.55 & 4.00 & 3.80 & 15.20 & -1.818 & -1.645 & Rejected \\
\hline 7. & $\begin{array}{l}\text { Order processing } \\
\text { time }\end{array}$ & 3.63 & 0.860 & 3.63 & 13.18 & 4.00 & 3.63 & 14.52 & -4.471 & -1.645 & Rejected \\
\hline 8. & Shipping cost & 3.49 & 1.037 & 3.69 & 12.88 & 4.00 & 3.69 & 14.76 & -5.111 & -1.645 & Rejected \\
\hline 9. & $\begin{array}{l}\text { Easy and secured } \\
\text { payment method }\end{array}$ & 3.75 & 1.024 & 3.76 & 14.10 & 4.00 & 3.76 & 15.04 & -2.537 & -1.645 & Rejected \\
\hline 10. & $\begin{array}{l}\text { Return/refund } \\
\text { facility if needed }\end{array}$ & 3.15 & 0.895 & 2.90 & 9.14 & 4.00 & 2.90 & 11.60 & -9.870 & -1.645 & Rejected \\
\hline 11. & $\begin{array}{l}\text { Activeness of } \\
\text { customer care }\end{array}$ & 3.01 & 0.881 & 3.24 & 9.75 & 4.00 & 3.24 & 12.96 & -11.678 & -1.645 & Rejected \\
\hline & & & & & 145.23 & & & 159.24 & & & \\
\hline
\end{tabular}

To test the hypothesis left tailed $\mathrm{Z}$ test is used at $5 \%$ significance level, because the null hypothesis reflects that $b_{i} \geq 4$ which requires left tailed $Z$ test. At the $5 \%$ significance level with 30 or more samples the critical value of $\mathrm{Z}$ is 1.645. If the computed value of $\mathrm{Z}$ is more than the critical value then $\mathrm{H}_{0}$ is accepted otherwise rejected. 
Figure 4 : Acceptance/Rejection region of $\mathrm{Z}$ in case of left tailed at 5\% sig. level

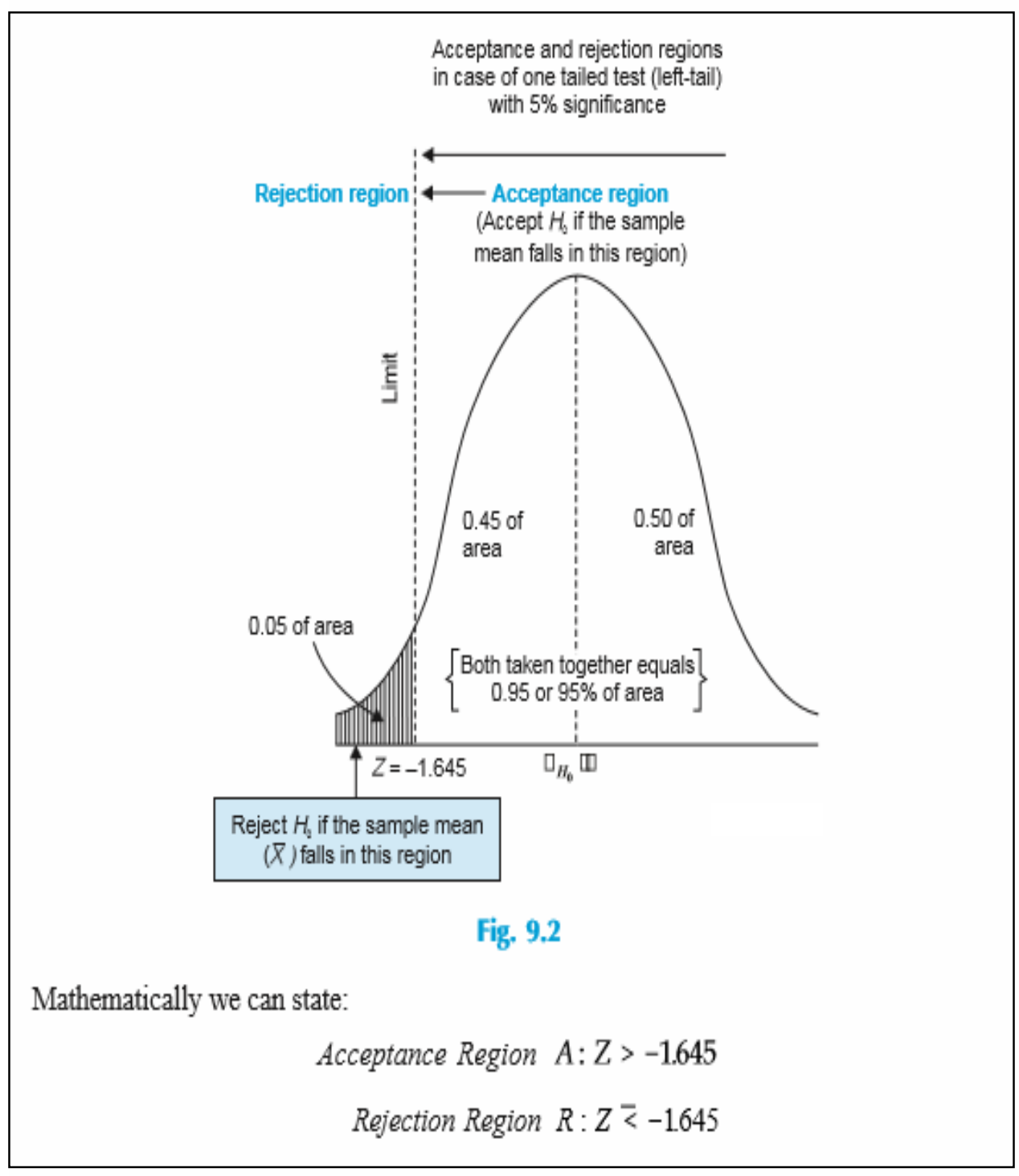

The computed values of $\mathrm{Z}$ (for $\mathrm{b}_{\mathrm{i}}$ ) mentioned in the above table are calculated by using the formula; 


$$
Z=\frac{\bar{x}-\mu_{H_{0}}}{\frac{\sigma_{s}}{\sqrt{n}}}
$$

Where,

$$
\begin{aligned}
& \quad \bar{x}=\text { Sample mean } \\
& \mu_{H_{0}}=\text { Hypothesized Population mean } \\
& \sigma_{s}=\text { Standard Deviation of Sample } \\
& n=\text { Sample size }
\end{aligned}
$$

The observed attitude $\mathbf{A}_{\mathbf{0}}=\mathbf{1 4 5 . 2 3}$ and the Hypothesized (expected) attitude is $\mathbf{A}_{\mathbf{0}}=\mathbf{1 5 9 . 2 4}$.

According to the result of hypothesis test the $\mathrm{H}_{0}$ is rejected at $5 \%$ significance. If we consider factor wise hypothesis only $\mathrm{H}_{0}$ is accepted against two factors namely Easiness of information searching opportunity and graphical interface of the website among the eleven factors. Against remaining nine factors $\mathrm{H}_{0}$ is rejected that means customers belief about those attributes is not favorable.

Figure 5: Factor Wise Customers' Belief about the Performance of E-Commerce Sites

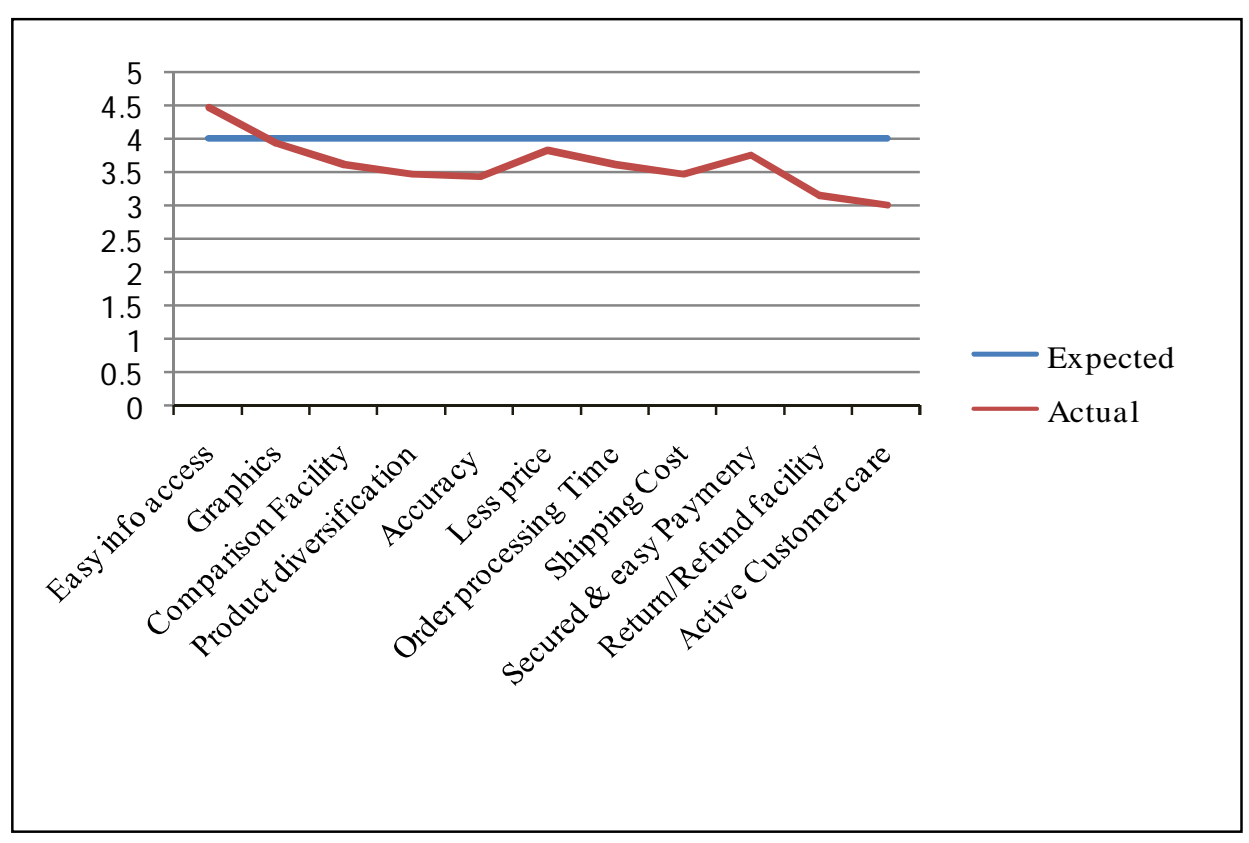




\section{FINDINGS AND RECOMMENDATIONS}

Most of users specifically $60.20 \%$ visit a particular e-commerce website by clicking promoted link or ad on other website they visit like facebook, search engines, public mail servers etc. So e-commerce sites should be promoted on target websites.

Large numbers of customers, $38.90 \%$ prefer cash on delivery payment system that means they don't rely on advance payment before receiving the products. But this payment system creates some risks of non-delivery of sent products due the non-payment by the customers. So e-commerce sites should increase their reliability to the customers, they can introduce product return and cash back facilities to minimize this problem.

According to the evaluation $\left(e_{i}\right)$ among the eleven attributes of e-commerce site most important attribute is Easy information searching opportunity, second important is Less price than physical stores, thirdly Easy and secured payment method, least important attribute is Return/refund facility if needed and Activeness of customer care. So e-commerce sites should improve their performance based on the most important attributes.

Only on two factors, easy information accessibility and graphics quality of the site among eleven factors $\mathrm{H}_{0}$ is accepted. That means customers formed standard positive belief ( 04 or above out of 05 ) on two attributes only. These two attributes are technical performance of website most of the remaining attributes are related to the business performance of the sites. The performances of these remaining nine attributes are not at enough standards to get desired positive perceptions. So e-commerce sites should concentrate their attention to improve the quality of business performance of their sites.

\section{CONCLUSIONS}

With the rapid growth of using smart phone, internet and the growth of internet banking and online banking, e-commerce is growing parallel. The Government of Bangladesh also gives priority to development the "digital Bangladesh", which enhances the potentiality of e-commerce here. So a huge opportunity is waiting for e-commerce sites. But the success factors are lying on the capacity of developing e-commerce site based on different important attributes according to the customers' preference. Only the information availability and graphical interface of the website customers' attitude is up to the benchmark and to others researched factors (i.e. product variety, accuracy, price, shipping cost, delivery time, service, refund etc.).Customers' attitude towards ecommerce website of Bangladesh is not enough make to captivate the customers. So the e-commerce entrepreneurs and all others involved with this emerging industry should take customers' attitude seriously for future growth. 


\section{REFERENCES}

Akbar, S., \& James, T. P. (2014). Consumers' attitude towards online shopping: Factors influencing employees of crazy domains to shop online. Journal of Management and Marketing Research, 14, 1-11.

Bangladesh Bureau of Statistics, Home, BBS. Retrieved January 12, 2015, from BBS website: http://www.bbs.gov.bd/home.aspx

Bangladesh Telecommunication Regulatory Commision, (2015, January 18). Retrieved from BTRC wesite: http://www.btrc.gov.bd/content/internet-subscribersbangladesh-january-2015

Bank, W. (2015, January 05). World Bank: Country data. Retrieved from World bank website: http://www.worldbank.org/en/country/bangladesh

Bhatt, A. (2014). Consumer Attitude towards Online Shopping in Selected Regions of Gujarat. Journal of Marketing Management, 02 (02), 29-56.

Bhowmik, Roni \& Daoyi.(2012).The present e-commerce situation in Bangladesh for B2C

e-commerce.International Journal of Economics and Research, 3 (5), 77.

Harisur, Mohammadet al. (2012). Developing Online Shopping Intention among People: Bangladesh

Perspectiv.Developing Country Studies.2 (9) 69-70.

Haque, Ahasanul \& Khatibi. Ali (2007). The Impact of Internet marketing on customer satisfaction: A

study Malaysian perspective.Journal of Mobile communication.1 (1) 29-35.

Hossain, Md. Akbor et al. (2013).A Survey of E-Commerce of Bangladesh. International Journal of Science and Research (IJSR).2 (2) 155-157.

Jusoh, Z. M., \& Ling, G. H. (2012). FACTORS INFLUENCING CONSUMERS' ATTITUDE TOWARDS E-COMMERCE PURCHASES THROUGH ONLINE SHOPPING. International Journal of Humanities and Social Science, 02 (04), 223-230.

Laudon, K. C., \& Traver, C. G. (2014). E-Commerce: business. technology. society. New Delhi: Prentice Hall.

LEONARD, L. N. (2012). ATTITUDE INFLUENCERS IN C2C E-COMMERCE: BUYING AND SELLING. Journal of Computer Information Systems, 11-17. 
Martin Fishbein (1963), An Investigation of the Relationship between Beliefs about an object and the attitude towards that object, Human Relations, August 16, 233240.

Momtaz, Hasinaet. al. (2011).Customers Satisfaction on Online Shopping in Malaysia.International

Journal of Business and Management. 6 (10) 163-164.

Nikalje, V. (2013). To Study Factors That Influence the Attitude of Consumers towards Online Shopping in City of Pune. International Center for Business Research, $02,1-5$.

Owens, T. R., \& Sarov, M. G. (2010). Determinants of Consumer Attitudes Towards E-commerce. Issues in Political Economy, 19, 29-50.

Ramdhani, A., Alamanda, D. T., \& Sudrajat, H. (2012). Analysis of Consumer Attitude Using Fishbein Multi-Attributes Approach. International Journal of Basic and Applied Science, 01 (01), 33-39. 